\title{
DEMAND MODEL OF ORIGIN AUSTRALIA BEEF IMPORTS AND DOMESTIC BEEF PRODUCTION
}

\author{
Maruli Pahantus* \\ Faculty of Animal Science, University of Jambi, Indonesia \\ Minha Amruzi, Susetyo Didik, Adriani Dessy \\ Faculty of Agriculture, University of Sriwijaya, Indonesia \\ *E-mail: pahantusmarulihutabarat@yahoo.com
}

\begin{abstract}
The volume of beef imports from Australia increased enormously, while domestic beef production in few slow growth. This study aimed to analyze the demand for beef imports from Australia as well as domestic beef production Indonesia. The type of data that will be used in this research is data sequential time (time series) in the period 1990-2014. The price data obtained from the Ministry of Trade and the FAO and the Ministry of Agriculture. Imports of beef from the authority of Australia (Australian Bureau of Statistics, Meat Livestock Association, and the Australian Bureau of Agricultural and Resource Economics and Sciences). This research was conducted by econometric analysis. Imports of beef from Australia, influenced by the price of Australian beef, cattle imports from Australia, imports of beef origin other than Australia, and the price of beef imports from Australia. While domestic beef production or in the country affected by the imports of Australian beef and domestic beef consumption.
\end{abstract}

\section{KEY WORDS}

Import, production, beef, consumption.

Soaring demand for meat at certain times combined with inventory less likely to cause large price fluctuations. The government was forced to resolve this issue as quickly as possible to add inventory to supply beef. Imports of meat necessary for farmers to have enough time to produce more cattle in order to increase domestic supplies. With the imported cattle in the market, ideally farmers no longer depressed the demand for meat and can keep their cows for breeding rather than slaughter. But it is also the sacrifice. As a result of the import of meat available on the market, the price of meat to be down and farmer income also fell. Moreover, import liberalization cannot be done continuously since it was more advantageous other countries due to the size of the market opened Indonesia. It has been noted in the case of South Korea were liberalized so many countries competing to meet domestic demand South Korea (Kim et al, 2004).

On the demand side, consumption of beef per capita of Indonesia has increased sharply in 1993 of $0.704 \mathrm{~kg}$ per capita per year, being $4.086 \mathrm{~kg}$ per capita per year in 1996 . At the time of the economic crisis of 1997, this number plummeted to the level of $1446 \mathrm{~kg}$ per capita in 1999 and slowly climbed back slowly since 2002 to reach 2,360 kg per capita per year in 2014. on the supply side, production data from 1984 to 2015 cows actually increasing. In 1984, Indonesia produced cows as 248.48 thousand tons, 151.58 or $61 \%$ met by the rest of Java and outside Java. In 1993, national production reached 346.28 thousand tons, $71 \%$ supplied from Java. In 2015 , beef production in the country reached 523.93 thousand tons to supply Java is still at $58 \%$.

With the research gap in demand for beef imports and its impact on cattle production in the country, the present study will try to study the effect of these cattle imports in the context of Indonesia's domestic cattle industry. Factors known to affect imports in the study of Nguyen and Jolly (2010) is the exchange rate, revenue, tourism, and trade policies. This 
study was to analyze the behavior of domestic cattle production and demand for beef imports from Australia in Indonesia as well as domestic cattle production.

\section{METHODS OF RESEARCH}

The type of data that will be used in this research is data sequentially (time series) year period from 1990 to 2014. Price data obtained from the Ministry of Trade and the FAO and the Ministry of Agriculture. Data productivity of local cattle from the Ministry of Agriculture, imports of the previous and current as well as the development of related industries from the Ministry of Commerce, the per capita income of BPS, the proportion of imports in advance of the authority of Australia (Australian Bureau of Statistics, Meat Livestock Association, and the Australian Bureau of Agricultural and Resource Economics and Sciences).

This research was conducted by econometric analysis. Econometric analysis is the measurement and quantitative analysis of economic phenomena and actual business (Studenmund, 2012).

Equality of domestic meat production:

$$
P D S D o_{t}=a_{0}+a_{1} I D S A_{t}+a_{2} I D S s A_{t}+a_{3} K D S D o_{t}+a_{4} P O S D o_{t}+a_{5} \text { DPSDS }_{t}+a_{6} \text { TIDS }_{t}+U_{1}
$$

Equation beef imports from Australia was formulated as follows:

$$
\text { IDSA }_{t}=b_{0}+b_{1} H_{D S A}+b_{2} \text { PDSDo }_{t}+b_{3} N_{T R}+b_{4} I S H A_{t}+b_{5} \text { TIDS }_{t}+b_{6} I D S s A_{t}+b_{7} H_{I D S A}+U_{2}
$$

Equation domestic beef meat prices can be written as:

$$
\text { HDSDot }=\mathrm{C}_{0}+\mathrm{C}_{1} \mathrm{HIDSA}_{\mathrm{t}}+\mathrm{C}_{2} \mathrm{KDSDo}_{\mathrm{t}}+\mathrm{C}_{3} \mathrm{HDSDu}_{\mathrm{t}}+\mathrm{C}_{4} \mathrm{HDSA}_{\mathrm{t}}+\mathrm{U}_{3}
$$

Equation domestic beef consumption is formulated as follows:

$$
K D S D o_{t}=d_{0}+d_{1} P d d k+d_{2} P D B_{t}+d_{3} P D S D o_{t}+d_{4} I D S A_{t}+d_{5} I D S s A_{t}+U_{4}
$$

Equations price of beef imports from Australia was formulated as follows:

$$
\operatorname{HIDSA}_{t}=e_{0}+e_{1} \mathrm{HDSDu}_{t}+\mathrm{e}_{2} I D S A_{t}+e_{3} \text {ToEDSA}_{t}+\mathrm{e}_{4} \text { TIDS }_{t}+\mathrm{e}_{5} \mathrm{POSA}_{t}+\mathrm{U}_{5}
$$

Signs estimate the expected parameters are as follows:

$$
\begin{gathered}
a_{1}, a_{2}, a_{3}, a_{4}, a_{5}, a_{6}, a_{6}>0 \\
b_{3},>0 ; b_{1}, b_{2}, b_{4}, b_{5}, b_{6}, b_{7}<0 \\
c_{1}, c_{2}, c_{3}, c_{4},>0 \\
d_{1}, d_{2}, d_{3}, d_{4}, d_{5}>0 \\
e_{1}, e_{3}, e_{5},>0 ; \text { and } e_{2}, e_{4}<0
\end{gathered}
$$

Where: $\mathrm{PDSDo}_{\mathrm{t}}=$ Total Domestic Beef Production / Homeland (tons); IDSA $_{t}=$ Volume of beef imports from Australia $(\mathrm{kg})$; $\mathrm{HDSDo}_{t}=$ Domestic beef price (US $\$ / \mathrm{kg}$ ); $\mathrm{KDSDo}_{t}=$ Domestic beef consumption (tons); $\mathrm{HIDSA}_{\mathrm{t}}=$ Price of beef imports from Australia (US \$ / kg, CIF); IDSA $A_{t}=$ Volume Beef imports from Australia $(\mathrm{kg}) ;$ IDSsA $_{t}=$ Volume of Imported Beef origin other than Australia $(\mathrm{kg}) ; \mathrm{KDSDo}_{t}=$ Domestic beef consumption (tons); $\mathrm{POSDo}_{\mathrm{t}}=$ Domestic Cattle population (head); DPSDS = Dummy Beef Self-Sufficiency Program; TIDS $_{t}=$ Beef Import Tariff (\%); HDSA ${ }_{t}=$ Australian beef price (US \$ / kg); $\mathrm{PDSDo}_{\mathrm{t}}=$ Domestic beef production (tons); NTR $=$ Exchange Rate (Rp./US\$); $I_{S H A}=$ Imports of Cattle on Australia $(\mathrm{kg})$; $\mathrm{HDSDu}_{\mathrm{t}}=$ World beef prices (US $\$ / \mathrm{kg}$ ); $\mathrm{Pddk}_{\mathrm{t}}=$ Total population (People); $\mathrm{PDB}_{\mathrm{t}}=$ Gross domestic product per capita (US \$ / capita); ToEDSA $_{t}=$ Total volume of imports of Australian beef $(\mathrm{kg})$; Posa Po $_{\mathrm{t}}=$ Australian Cattle population (head); U1-5 = Confounding variables. 
This study used an econometric approach to the system of simultaneous equations. The formulation of a structural equation model identification based order condition is as follows (Koutsoyiannis 1977):

$$
(K-M)>(G-1)
$$

Where: $\mathrm{K}=$ total number of variables in the model, i.e. the number of endogenous variables and predetermined variables; $M=$ number of endogenous and exogenous variables are included in a specific equations in the model; $G=$ total equations in the model, ie the number of endogenous variables in the model.

If a model's equations indicate the following conditions:

- $\quad(K-M)>(G-1)=$ the equation expressed identifiable excess (over-identified);

- $(K-M)=(G-1)=$ the equation expressed appropriately identified (identified exactly);

- $\quad(K-M)<(G-1)=$ the equation otherwise unidentified (unidentified).

After the identification and estimation models, model validation stage is then performed. Test the validity of the model that is often used is the Root Means Squares Error (RMSE), Root Mean Squares Error Percent (RMSPE), and Theil's Inequality Coefficient (UTheil). These criteria are formulated as follows (Pindyck and Rubinfeld 1998a):

$$
\begin{aligned}
R M S E & =\sqrt{\frac{1}{n} \sum_{t=1}^{n}\left(Y_{t}^{s}-Y_{t}^{a}\right)^{2}} \\
R M S P E & =\sqrt{\frac{1}{n} \sum_{t=1}^{n}\left(\frac{Y_{t}^{s}-Y_{t}^{a}}{Y_{t}^{a}} x 100\right)^{2}} \\
U & =\frac{\sqrt{\frac{1}{n} \sum_{t=1}^{n}\left(Y_{t}^{s}-Y_{t}^{a}\right)^{2}}}{\sqrt{\frac{1}{n} \sum_{t=1}^{n}\left(Y_{t}^{s}\right)^{2}+\sqrt{\frac{1}{n} \sum_{t=1}^{n}\left(Y_{t}^{a}\right)^{2}}}}
\end{aligned}
$$

Where: $Y_{-} t^{\wedge} \mathrm{s}=$ the value of the basic simulation results of observation variable; $\mathrm{Y}_{-}{ }^{\wedge}{ }^{\wedge} \mathrm{a}=$ the actual value of the variable observation; $\mathrm{n}=$ number of observation periods.

\section{RESULTS OF STUDY}

Analysis of Two-Stage Least Squares (2SLS) can only be done on an equation that was classified Exactly Identified or Over.

Table 1 - Terms Order in Equation

\begin{tabular}{lllll}
\hline No & Equation & $\mathrm{K}-\mathrm{k}$ & $\mathrm{M}-1$ & Order Condition \\
\hline 1 & IDSA & $17-8=9$ & $5-1=4$ & Over Identified \\
2 & PDSDo & $17-7=10$ & $5-1=4$ & Over Identified \\
3 & KDSDo & $17-6=11$ & $5-1=4$ & Over Identified \\
4 & HDSDo & $17-5=12$ & $5-1=4$ & Over Identified \\
5 & HIDSA & $17-6=11$ & $5-1=4$ & Over Identified \\
\hline
\end{tabular}

Note: IDSA - Beef imports from Australia; PDSDo - Domestic Beef Production; KDSDo - Beef Domestic Consumption; HDSDo - Domestic Beef Prices; HIDSA - Beef Import Price of Australia.

The estimation results are presented is a model equation which has been amended several times. These results are considered the best because it has met the criteria of economy, statistics and econometrics. Based on the test results to the classical assumption 
violation, concluded a model built not experience classic assumption collision. The resulting estimated parameters already meet the rule BLUE (Best, Linear, and Unbiased Estimator).

The results of the analysis of Two-Stage Least Squares (2SLS) to the equation Beef imports from Australia (IDSA) obtained $\mathrm{R}^{2}$ of 0.9178 . Based on Table 2. it can be stated that the Australian Beef Imports (IDSA) is affected by the price of Australian beef, cattle imports from Australia, imports of cattle origin other than Australia, and the price of beef imports from Australia. The results are consistent with the results Priyanto (2003) using data from 19802000 also showed similar results. However, there is a difference with several other studies that showed a negative relationship between the prices of beef imports with volume of imports of beef, but the effect is not noticeable as the study by Ilham (1998), Kariyasa (2004), and Tseuoa (2011). And research results Kusriatmi (2014) showed that the rise in prices of imported beef tends to increase the volume of beef imports, but the effect was not significant $(p>0.2)$.

Table 2 - Results of Estimation Equation Beef imports from Australia (IDSA)

\begin{tabular}{llcl}
\hline Variable & & Parameter Estimation & Probability $>(\mathrm{t})$ \\
\hline IDSA & & Beef imports from Australia & \\
C & Constanta & 2388411. & 0.9100 \\
HDSA & Price Beef Australia & -10554704 & 0.0148 \\
PDSDo & Domestic Beef Production & -32.67571 & 0.5751 \\
NTR & Rupiah exchange rate & 300.8752 & 0.7525 \\
ISHA & Beef imports from Australia Life & 0.090569 & 0.0135 \\
TIDS & Beef Import Tariff & -125642.7 & 0.7469 \\
IDSsA & Import Beef origin than Australia & 0.663647 & 0.0106 \\
HIDSA & Beef Import prices from Australia & 13563046 & 0.0136 \\
\hline & $R^{2}$ & 0.917796 & 0.0000 \\
\hline
\end{tabular}

The findings of this study concluded that the number of cattle imports from Australia increased the total volume of beef imports from Australia also increased, whereas the number of cattle imports from Australia decreased the total volume of beef imports from Australia were also reduced. Conditions findings of this study explains that the import of beef from Australia to import cattle from Australia are complementary (complementary) is not interchangeable (substitution).

Furthermore, imports of beef origin than Australia increased the total volume of beef imports from Australia also increased, whereas imports of beef origin than Australia reduced the volume of beef imports from Australia decreased. The results of this study concluded that the origin of beef imports in addition to Australia with beef imports from Australia are complementary (complementary) is not interchangeable (substitution).

Based on Table 2 it can be stated that the Australian Beef Imports (IDSA) are not affected by domestic beef production, exchange rate and import tariff beef. These results differ from Kusriatmi study (2014), the low growth in cattle production nationwide to encourage increased imports of cattle and beef to meet demand for beef is increasing. Imports made for national meat production cannot meet consumption. Such conditions lead to competition between domestic beef products with imported beef products. Local beef production has negative and statistically significant against the volume of imports of beef ( $p$ $<0: 01)$.

However, in line with the results Priyanto (2003), namely beef imports are less affected by fluctuations in the exchange rate penelitiani results are not in line with the results Kusriatmi (2014) Indonesia is a price taker related to import beef products. In this case the stability of the exchange rate will affect the price of imported beef cattle industry and national development.

In the simultaneous equations for Domestic Beef Production (PDSDo) method TwoStage Least Squares coefficient of determination $\left(R^{2}\right)$ of 0.9615 . Domestic Beef Production (PDSDo) is affected by imports from Australia Beef and Beef Domestic Consumption. These findings suggest that beef imports from Australia increased the domestic beef production to decline, contrary beef imports from Australia decreased then increased domestic beef 
production. According Rusastra (2014), the national beef supply sources are determined by the 6.4 million small farmers of traditional, 96 importers of cattle, and 67 importers of beef. To meet the needs of domestic beef, Indonesia to import beef from several countries, mainly from Australia and New Zealand. Meat imports in the form of frozen beef (frozen) and fresh / chilled (fresh / chilled) mainly to meet the demand for high-quality meat by super markets, hotels, and a great restaurant (Hadi et al. 1999).

Table 3 - Estimation Equation Domestic Beef Production (PDSDo)

\begin{tabular}{llll}
\hline Variable & & Parameter Estimation & Probability $>(\mathrm{t})$ \\
\hline PDSDo & Domestic Beef Production & & \\
C & Constanta & 139979.7 & 0.0118 \\
IDSA & Beef imports from Australia & -0.002215 & 0.0149 \\
IDSsA & Beef imports & 0.001457 & 0.1323 \\
KDSDo & Beef Domestic Consumption & 1.555181 & 0.0000 \\
OSDo & Domestic Cattle Population & -0.010842 & 0.0684 \\
PSDS & Beef Self-Sufficiency Program & -2671.213 & 0.8395 \\
TIDS & Beef Import Tariff & -437.4420 & 0.3627 \\
\hline & $R^{2}$ & 0.961510 & \\
& F-statistic & 72.67548 & 0.0000 \\
\hline
\end{tabular}

Domestic beef consumption per capita increased considerably within the last 25 years. Proven domestic beef consumption in 1990 as much as $0.88 \mathrm{~kg} /$ capita is very high it means an increase to as much as $1.72 \mathrm{~kg} /$ capita in 2014, rising by an average of $3.32 \%$ per year. According Yusdja et al (2004) in the last 10 years consumption of beef demand continues to increase and has exceeded the ability of domestic beef production.

Domestic Beef Production (PDSDo) are not affected by the imports of beef origin than Australia, domestic cattle population, Beef Self-Sufficiency Program (PSDS) and beef import tariffs.

Imports of beef origin than Australia does not affect domestic beef production due share of beef imports origin than Australia versus total beef imports decreased throughout the years 1990-2014. On the average share of imported beef origin other than Australia which is $44.71 \%$ per year over the last 25 years. In 1990, the share of imported beef origin than Australia versus total beef imports is further decreased $72.46 \%$ in 2014 amounting to $22.15 \%$.

Domestic cattle population not affects domestic beef production due to domestic cattle population rose an average of $1.64 \%$ per year. According to Yusdja and Inspiration (2004) national cattle population growth rate based on secondary data provided in the last 30 years is only 1.44 percent. Such growth is considered to be very slow, and even some areas of production the number of cows has decreased. While the development of domestic beef production in the same period (1990-2014) with a tendency to fluctuate increased from 259.2 million tonne in 1990 to 545621000 per ton, or an average growth of 3.80\% per year.

Beef self-sufficiency program that consists of Beef Sufficiency Program 2005 is listed in the strategic plan of the Directorate General ranch Year 2010-2005, Policies to Accelerate Achievement of Self-Sufficiency Beef (P2SDS) by the Minister of Agriculture No: 59/Permentan/HK.060/8/2007 on Guidelines to Accelerate Achievement of Self-sufficiency beef and beef Self-sufficiency Program Policy 2014 by the Minister of Agriculture No. 19/Permentan/OT.140/ 2/2010 on General Guidelines for Self-sufficiency Program 2014. beef beef self-sufficiency program is not successfully increase domestic beef production, while a side of beef domestic consumption continues to increase so as not to suppress the price of domestic beef. According to the Department of Commerce (2008), the rate of demand for beef that is higher than the rate of supply of local meat causing domestic beef prices continue to rise, so the supply of imports continued to grow in size.

Beef import tariffs did not affect domestic beef production. These results differ from Tseuoa research, et al. (2011) on the impact of the ASEAN Australia and New Zealand Free Trade Agreement (AANZFTA) against the cattle industry in Indonesia by using econometric models indicate that the elimination of tariffs on imports of beef for imports from Australia and 
New Zealand in AANZFTA will reduce beef production in the country, increase imports of beef and beef domestic deals, and lower the price of beef in the country so demand for beef increases.

Simultaneous equation model with the method Two-Stage Least Squares for Beef Domestic Consumption (KDSDo) has a coefficient of determination $\left(R^{2}\right)$ of 0.9771 . The t-test showed that the model of simultaneous equations Domestic Beef Consumption (KDSDo) affected by domestic beef production, beef imports from Australia, and imports of beef origin other than Australia.

These conditions explain that domestic beef production increases, the domestic beef consumption also increased, whereas domestic beef production declining, domestic beef consumption also declined. Based on data in 1990-2014 turned out to be the development of domestic beef consumption followed by the development of domestic beef production, which is the average domestic beef production grew by $3.27 \%$ per year and the average domestic beef consumption grew by $4.79 \%$ per year.

Table 3 - Results Estimation Equation Domestic Beef Consumption (KDSDo)

\begin{tabular}{llll}
\hline Variable & & Parameter Estimation & Probability $>(\mathrm{t})$ \\
\hline KDSDo & Beef Domestic Consumption & & \\
C & Constanta & 49187.15 & 0.3210 \\
Pddk & Total population & -0.287917 & 0.4161 \\
PDB & Gross domestic product & 12.46914 & 0.1187 \\
PDSDo & Domestic Beef Production & 0.609495 & 0.0001 \\
IDSA & Beef imports from Australia & 0.001768 & 0.0010 \\
IDSsA & Import Beef origin than Australia & -0.001274 & 0.0429 \\
\hline & $R^{2}$ & 0.977107 & \\
& F-statistic & 158.8406 & 0.0000 \\
\hline
\end{tabular}

During Indonesia's beef needs met from three sources, namely local beef, imported cattle and beef imports. To cover the shortage of beef in the country deals that imported from various countries, mainly Australia and New Zealand (Kusriatmi, 2014; Ilham 2009; Maraya, 2013; Istiqomah, 2014). Over the last ten years the rate of growth of imports of beef likely to experience a significant increase that in 2011 the number of beef imports amounted to $35.59 \%$ and the number is increasing beef imports in 2012 reached $42.08 \%$. The proportion of the development of beef imports have increased along with the increasing consumption of beef in the country (Directorate General of Livestock and Animal Health, 2013).

Simultaneous equation model Beef Domestic Consumption (KDSDo) by t-test is not influenced by population and Gross Domestic Product (GDP). The results of this study differ from Priyanto (2003), an evaluation of the beef import policy in order to protect domestic farmers using the approach of supply and demand analysis. Priyanto study using an econometric model, where the conclusion is the national meat consumption is influenced by the number of inhabitants and responsive to changes in population size.

Changes (increase or decrease) Pproduk GDP per capita does not cause a change (increase or decrease) in domestic beef consumption. The findings of this study are not consistent with research Chern et al., (2002) on the Analysis of Food Consumption Behavior by Japanese Household stated that increasing per capita income lead to increased consumption of beef. Further research Haley (2001) states that there is a positive correlation between levels of income and consumption per capita meat consumption of red meat (beef, veal, pork, lamb and mutton) from the years 1970-2000. Ilham Research (1998), per capita income of the people of Indonesia provides a real influence on consumption of beef.

Simultaneous equation model to price Domestic Beef (HDSDo) has a $R^{2}$ of 0.9314 . Then the analysis results obtained estimates of 69.93436 Fstatistik value with the value of Prob. (F-statistic) of 0.0000 . Table 4 based on that price Domestic Beef (HDSDo) is influenced by the price of domestic beef and Australian beef prices.

Explanatory domestic beef consumption increases, the domestic beef prices also increased, otherwise domestic beef consumption declining, domestic beef prices also declined. Increased domestic consumption of beef in the period of last 25 years was followed 
by an increase in the price of domestic beef. Data proves that domestic beef consumption increased by an average $4.79 \%$ per year and the price of domestic beef in the same period the average growth of $7.67 \%$ per year. According to the Ministry of Agriculture (2015), the increase in the price of beef is the case today as a result of an imbalance between production quotas and the high public demand for beef.

Table 4 - Results of Equations Estimated price Domestic Beef (HDSDo)

\begin{tabular}{llll}
\hline Variable & & Parameter Estimation & Probability $>(\mathrm{t})$ \\
\hline HDSDo & Domestic Beef Prices & & \\
C & Constanta & -0.619525 & 0.6142 \\
HIDSA & Beef Import prices from Australia & 0.843518 & 0.0639 \\
KDSDo & Beef Domestic Consumption & $1.34 \mathrm{E}-05$ & 0.0100 \\
HDSDu & Price Beef World & -0.762080 & 0.1773 \\
HDSA & Price Beef Australia & 1.088270 & 0.0090 \\
\hline & $\mathrm{R}^{2}$ & 0.931423 & \\
& F-statistic & 69.93436 & 0.0000 \\
\hline
\end{tabular}

The findings of this study inform that Australian beef price increases, domestic beef prices also increased, otherwise the price of Australian beef are declining, domestic beef prices also declined. Australian beef price development during the period of 1990-2014 are relatively less volatile with a tendency increased from 1,708 US \$ per kg in 1990 to 2,235 US $\$$ per $\mathrm{kg}$ on average grew only by $1.80 \%$ per year. When compared to the world price of beef, beef prices Australia for 25 years is always lower, which is the average difference (gap) of 1.088 US \$ per kg per year. Similarly, when compared to the price of Australian beef to domestic beef prices, is also always lower that the average difference (gap) of 2.605 US \$ per kg per year.

Research on the beef market integration has been done in some countries, such as research Diakosavvas (1995) using cointegration analysis based on linear regression approach. The purpose of research is to test the market integration between the prices of beef Australia and the United States (US) at the farm level by using monthly time series data from 1972 to 1993. The results showed cointegration was found between the prices of beef Australia and the United States. Convergence analysis shows the level of convergence between various pairs prices have not increased over time. The results show that the price of Australian beef cannot be adopted as the world price of an empirical analysis.

In Table 4 Domestic Beef Price (HDSDo) are not affected by the price of beef imports from Australia and the world beef prices. The results of this study differed with Zainuddin et al (2015), normatively, beef prices the world will be positive effect on beef prices domestically, because if the price of beef world or beef imports increased the price of beef domestic also increased, but on the contrary the price domestic beef can not affect the world price of beef due to the nature of unidirectional transmission only because Indonesia is a small country (net importer) with the proportion of Indonesia's imports amounted to only $0.91 \%$ of the amount of beef the world (FAO, 2014).

Model Import Price equation Australian Beef (HIDSA) by 2SLS method obtained $R^{2}$ of 0.8388. The results of estimation analysis ( $F$ test) Fstatistik values obtained at 20.07805 value Prob. (F-statistic) of 0.0000 . Beef Import prices from Australia (HIDSA) influenced by the world price of beef, beef imports from Australia, and the beef import tariffs.

World beef prices affect the price of beef imports from Australia, the world rising beef prices causing the price of beef imports from Australia increased, otherwise declining world beef prices caused import prices of meat from Australia declined.

Beef imports from Australia (IDSA) partially affect the price of beef imports from Australia. The effect is positive, ie the volume of beef imports from Australia increased causing prices of imported beef from Australia also increased, whereas the volume of imports of beef from Australia decreased causing the price of beef imports from Australia also declined.

Beef Import Tariff (TIDS) partially affect the price of beef imports from Australia. The effect is positive, that rate increased beef imports causing the price of beef imports from 
Australia also increased, whereas rates declining beef imports causing the price of beef imports from Australia also declined.

Table 5 - Estimation results Equation Beef Import Price of Australia (HIDSA)

\begin{tabular}{llll}
\hline Variable & & Parameter Estimation & Probability $>(\mathrm{t})$ \\
\hline HDSA & Australian Beef Prices & & \\
C & Constanta & -9.590128 & 0.0126 \\
HDSDu & Price Beef World & 0.898119 & 0.0047 \\
IDSA & Beef imports from Australia & $2.58 \mathrm{E}-08$ & 0.0072 \\
ToEDSA & Total Export Beef Australia & $1.47 \mathrm{E}-06$ & 0.3269 \\
TIDS & Beef Import Tariff & 0.052714 & 0.0090 \\
POSA & Australian Cattle Population & $2.51 \mathrm{E}-07$ & 0.0740 \\
\hline & $R^{2}$ & 0.838855 & 0.0000 \\
\hline
\end{tabular}

These results differ from Tseuoa research, et al. (2011) on the impact of the ASEAN Australia and New Zealand Free Trade Agreement (AANZFTA) against the cattle industry in Indonesia by using econometric models indicate that the elimination of tariffs on imports of beef for imports from Australia and New Zealand in AANZFTA will reduce beef production in the country, increase imports of beef and beef domestic deals, and lower the price of beef in the country so demand for beef increases. Alternative best policy to increase beef production in the country and reduce the import of beef is a combination of a reduction in the interest rate of four percent, raising cattle import of seeds of $60 \%$, improvement in technology of artificial insemination 64\%, and an increase in import tariffs on beef from Australia and New Zealand by $40 \%$. The combination of these policies can be implemented ahead of the implementation of the AANZFTA. Nevertheless, with this policy in 2014 Indonesia will reach only $52 \%$ self-sufficient in beef.

The liberalization of the beef market, where import duties on foreign beef to be lower than previously implications on the price of imported beef be much cheaper and the price of local beef which follows the movement of the price of beef imports also becoming more expensive than ever. This leads to fluctuations in the price of beef in the domestic market fully follow the market mechanism. Indonesia imported beef prices also fluctuate from year to year, but the changes in the world market does not mean also changes at the same rate on the price of beef imports Indonesia. Changes in world beef prices (import) will affect the consumption of beef Indonesian people who tend to be price-inelastic (Sutawi, 2007).

\section{CONCLUSION}

Beef production in the country the domestic or influenced by beef imports from Australia and domestic beef consumption, while domestic beef consumption, domestic cattle population, Beef Self-Sufficiency Program (PSDS), and the beef import tariffs does not affect the production of beef domestic or domestic. Imports of beef from Australia, influenced by the price of Australian beef, cattle imports from Australia, imports of beef origin other than Australia, and the price of beef imports from Australia. But domestic beef production, exchange rate, and the rates do not affect the import of beef imported beef from Australia. The consumption of domestic beef is influenced by domestic beef production, beef imports from Australia and imports of beef origin other than Australia. But the number of population and GDP do not affect domestic beef consumption.

\section{REFERENCES}

1. Chern, W.S et al, 2002. Analysis of Food Consumption Behavior by Japanese Household. Food and Agriculture Organization (FAO) of the United Nations.

2. Directorate General of Livestock and Animal Health. 2013. Animal Husbandry and Health Statistics (Livestock and Animal Health Statistics) 2012. Jakarta: Directorate General of Livestock and Animal Health Ministry of Agriculture of the Republic of Indonesia. 
3. Diakosavvas, D. 1995. How are World Beef Integrated Markets? The Case of Australian and U.S. Beef Markets. Agricultural Economics. 12 (2). 37-53.

4. FAO (2012) June 2016 Food Outlook. Geneva: FAO.

5. FAO (2014) May 2014 Food Outlook. Geneva: FAO.

6. FAO (2016) June 2016 Food Outlook. Geneva: FAO.

7. FAO (2016) October 2016 Food Outlook. Geneva: FAO.

8. Hadi P.U and Ilham N., 2002. Problems and Prospects of Development of Beef Cattle Breeding in Indonesia. Journal of Agricultural Research. 21 (4): 148-157.

9. Ilham, N. 1998. Beef Supply and demand in Indonesia: A Simulation Analysis. Thesis. Graduate Program of Bogor Agricultural University, Bogor.

10. Ilham, N. 2006. Economic Analysis and Strategy Achieving Self-Sufficiency Meat 2010. The paper presented at a meeting of the Technical Coordination Ruminant Aquaculture Directorate General of Animal Husbandry, Bogor.

11. Ilham, N. 2009. Meat Production Rarity: Indications and its Policy Implications. Agricultural Policy Analysis. Journal 7 (1). 43-63.

12. Ilham, N. (2014). Analysis of supply and demand for beef in Indonesia. JITV, 19 (3).

13. Istiqomah, N.S. (2014). Australia-Indonesia Cooperation in the Field of Export-Import Beef. Essay. Faculty of Social and Political Sciences, University of Hasanuddin.

14. Kariyasa, K. (2004). Supply and Demand Analysis in Indonesia Beef Prior and Current Economic Crisis: An Analysis of Self-Sufficiency Beef Projection 2005. SOCA (SocioEconomic Of Agriculture and Agribusiness), 4 (3).

15. Ministry of Trade. 2014. International Price Statistics 2008- 2013. Downloaded dated September 5, 2014 from http: //www.kemendag.internationalgo.id.

16. Ministry of Agriculture (2015). Agricultural Commodities Outlook Subsector Ranch Beef. Data and Information Systems General Secretariat of the Ministry of Agriculture.

17. Kim, R. B., Kim, Y. J., \& Veeman, M. (2004). Adjustments in the South Korean beef import market under liberalization policies. Agribusiness, 20 (2), 201-216.

18. Kim, R., \& Boyd, M. (2004). Identification of niche markets for Hanwoo beef: Understanding Korean consumer preference for beef using market segment analysis. International Food and Agribusiness Management Review, 7 (3), 46-64.

19. Kusriatmi (2014) Impact of Beef Self-Sufficiency Policy toward Economic Performance Subsector Ranch in Indonesia. Dissertation. IPB.

20. Nguyen, G. V., \& Jolly, C. M. (2010, January). Seafood Import Demand in the Caribbean Region. In 2010 Annual Meeting, February 6-9, 2010, Orlando, Florida (No. 56479). Southern Agricultural Economics Association.

21. Regulation of the Minister of Agriculture No. 59 / Permentan / HK.060 / 8/2007 on Guidelines to Accelerate Achievement of Self-Sufficiency Beef.

22. Regulation of the Minister of Agriculture No. 19 / Permentan / OT.140 / 2/2010 on General Guidelines for Self-Sufficiency Program Beef 2014.

23. Pindyck, R.S. and D. L. Rubinfied. Econometrics 1991. Models, and Economies Forecast. 3rd. Ed. McGraw-Hill Edition. Singapore.

24. Priyanto, D. 2003. Beef Import Policy Evaluation in the Context of Domestic Protection Breeder: Supply and Demand Analysis. Thesis. Graduate Program of Bogor Agricultural University, Bogor.

25. Priyanto, D. (2014). Beef Import Policy Evaluation through Supply and Demand Analysis. JITV, 19 (3).

26. Rusastra, I.W. 2014. Cattle and Beef Trade: Import Reconciliation Policy and Revitalization of Domestic Marketing. Agro Economic Research Forum, 1(32): 59-71.

27. Studenmund, A. (2017). Using econometric. 7th Edition. Boston: Pearson.

28. Tseuoa T. 2011. Impact of ASEAN Australia and New Zealand Free Trade Agreement on Beef Industry in Indonesia. Thesis. Graduate School of Bogor Agricultural University.

29. Yusdja, Y and Ilham, N. 2004. Agribusiness Development Policy Review of Beef. Journal of Agricultural Policy Analysis. Volume 2 No. 2, June 2004: 183-203.

30. Zainuddin, A. et al (2016). Integration Beef price in Domestic and International Market. Bulletin of Scientific Research and Trading, 9 (2), 109-128. 